\title{
Suitability of static tests for acid rock drainage assessment of mine waste rock
}

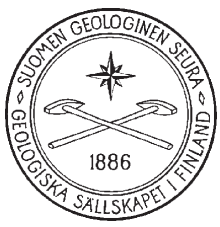

\author{
Marja LiISA RÄISÄNeN ${ }^{1) *}$, PäIVI M. KaUPPILA ${ }^{2)}$ \\ AND TIMO MYÖHÄNEN ${ }^{3)}$ \\ 1) Centre for Economic Development, Transport and the Environment for Kainuu, P.O. \\ Box 115, FI-87101 Kajaani, Finland \\ 2) Geological Survey of Finland, P.O. Box 1237, FI-70211 Kuopio, Finland \\ 3) Labtium Ltd, P.O. Box 1500, FI-70211 Kuopio, Finland
}

\begin{abstract}
In the present study, eight rock samples were analysed with a modified acid-base accounting (ABA) test and the corresponding net acid generation (NAG) test. In addition, the main and trace elements solubilised during the tests were determined with ICPOES/MS. Both the modified ABA and NAG tests classified the rock samples with a low sulphide-S content (0.1-0.4\%) and low carbonate mineral content $(\leq 0.2 \%)$ into the category of 'potentially acid generating'. The low neutralization potentials of these rocks were partly due to additional acid produced in silicate weathering, upon the hydrolyzation of Fe and Al during the tests. In contrast to the modified ABA, the contribution of slowly reactive carbonate minerals to the neutralisation potential was seen in the NAG test and in the carbonate NP calculation, as they classified the rock samples containing these minerals into the category of 'non-acid generating'. This supports the use of the carbonate neutralizing potential (NP) and/or the NAG test in mine waste screening. In the NAG test, acid generation and neutralization reactions either raising or decreasing the $\mathrm{pH}$ significantly influenced the solubility of trace metals and Al. This suggests that the extract contents could be useful in assessing contaminant mobility during long-term acid generating reactions.
\end{abstract}

Keywords: Static tests, modified ABA, single NAG test, neutralization potential, acid potential, mine waste, trace element extractability

*Corresponding author email: marja-liisa.raisanen@ely-keskus.fi

Editorial handling: Joonas Virtasalo

\section{Introduction}

Developers of new mines and operators of existing mines are required to prove that mine waste materials can be stored in a manner that will prevent or mitigate the generation of acid rock drainage (ARD), both during the operation and long after mine closure (Finnish Mine Waste Decree 717/2009). Acid- 
base accounting (ABA) tests, involving the determination of the acid generating potential (AP) and neutralizing potential (NP) of samples, are an essential part of waste characterization for ARD. These tests are designed to measure mining waste's capacity to produce and neutralize acidity, and do not provide information on reaction rates of mineral weathering. The tests are static in nature and allow simple, rapid and low-cost screening of waste samples to characterize whether the waste is either safe for disposal (NP exceeds AP) or potentially acid generating (AP exceeds NP) (Sobek et al., 1978; White et al., 1999; Jambor, 2003).

In the modified ABA test used in the present study (based on the preliminary standard prEN15875), the AP is based on the total sulphur content, assuming that the sulphur is entirely bound by the acid-producing sulphide minerals. The NP is determined by subjecting the sample to acid digestion, and it represents the amount of acid neutralizing carbonate minerals (or a limited range of silicates) in the sample (Kwong \& Ferguson, 1997). In this study, the 'modified NP' was determined using hydrochloric acid digestion at ambient temperature in controlled conditions of acidity to provide an end $\mathrm{pH}$ in the range of 2.0-2.5, prior to the $\mathrm{NaOH}$ titration (Lawrence \& Wang, 1997). For comparative purposes, NP was also determined based on the carbonate carbon content. This NP value is referred to as 'carbonate NP'.

The net acid generation (NAG) test is suitable for use both as a stand-alone prediction tool (Miller at al., 1997) and as a supplement to another static tests such as the modified ABA test above (Jambor, 2003). The test involves the reaction of a sample with hydrogen peroxide to rapidly oxidise any sulphide minerals in the sample. During the NAG test, acid generation and acid neutralization reactions can occur simultaneously. Therefore, the end-result represents a direct measurement of the net amount of acid generated by the sample.

The objective of the present study was to evaluate the suitability of a modified ABA test and the corresponding NAG test (AMIRA, 2002) for predicting ARD arising from waste rocks from metal mines and dimension stone quarries as well as crus- hed aggregate rocks with a low carbonate carbon and sulphide sulphur contents. The largest discrepancies in static tests and their interpretation arise in the assessment of the neutralization potential (Lawrence \& Scheske, 1997; Jambor, 2003). Therefore, the present study determined the NP with two methods: by the static NP test prEN15875, submitted for standardization to the European CEN committee, and based on the total carbonate carbon content converted to carbonate NP. Furthermore, the present study examined the metals and metalloids that solubilise during the tests, and evaluated the use of eluate composition in assessing the mobility of contaminants during long-term acid generating reactions. This has received less attention in earlier static test studies.

\section{Materials and methods}

The study materials consisted of four waste rock samples from metal mines (intermediate and mafic metavolcanic rocks, altered rock), three waste rock samples from dimensional stone quarries (soapstone, diabase, migmatite) and one aggregate rock sample (gneiss, Table 1). The soapstone, diabase, migmatite and mafic volcanic rock samples contained roughly less than $0.5 \%$ sulphide minerals, whereas the intermediate metavolcanic rock (IV) and altered rock samples contained abundant sulphide minerals ( $\geq 1 \%$ ) (Heikkinen et al., 2007; Dagenais \& Grondin, 2006; Räisänen, 2005). All the rock samples contained pyrrhotite and/or pyrite, which are obviously initial sources of potential acidity. Compared to the other samples, the mafic volcanic rock II (MVII) contained more chalcopyrite and pentlandite, whereas the intermediate metavolcanic rock sample was rich in arsenopyrite as well as pyrite and pyrrhotite (Dagenais \& Grondin, 2006). The diabase, gneiss and mafic volcanic rocks contained only a few carbonate minerals, which were abundant in the soapstone, altered rock and intermediate metavolcanic samples. The migmatite did not contain any carbonates (Table 1 ).

Prior to analysis, bulk rock samples (rock chips or chunks, and drill cores) were dried at $<40{ }^{\circ} \mathrm{C}$ and then crushed with a jaw crusher (Mn steel jaws). 
Table 1. Mineralogy of the studied rock samples (based on Heikkinen et al. (2007), Dagenais \& Grondin (2006) and Räisänen (2005).

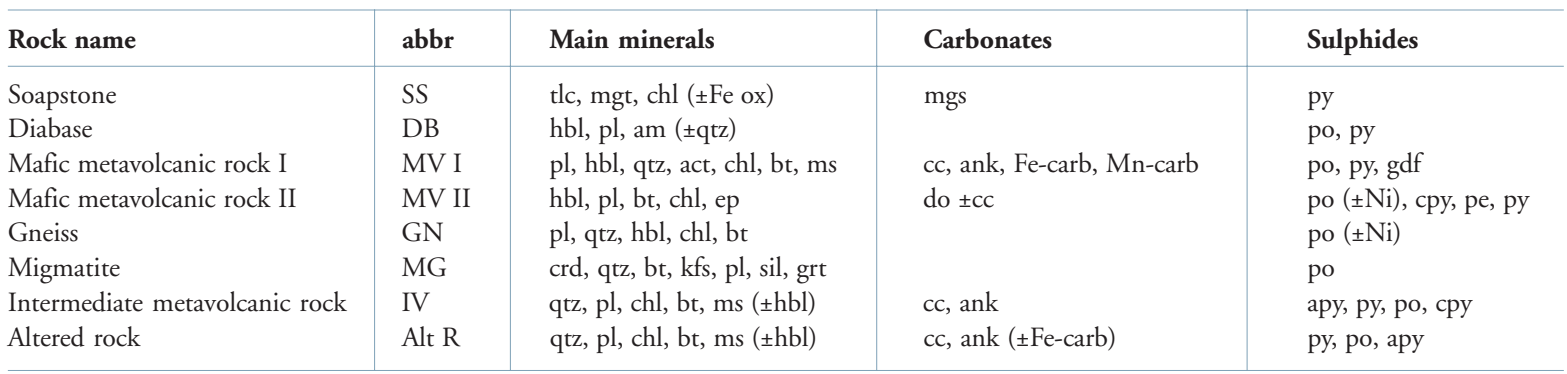

Abbreviations for the minerals: $\mathrm{pl}=$ plagioclase, $\mathrm{qtz}=$ quartz, $\mathrm{am}=$ amphibole, $\mathrm{hbl}=$ hornblende, act $=$ actinolite, $\mathrm{bt}=\mathrm{biotite}, \mathrm{ms}=\mathrm{muscovite}$, $\mathrm{crd}=$ cordierite, $\mathrm{kfs}=\mathrm{K}$ feldspar, $\mathrm{ep}=$ epidote, sill $=$ sillimanite, $\mathrm{grt}=$ garnet, $\mathrm{mgt}=$ magnetite, $\mathrm{tlc}=\mathrm{talc}, \mathrm{Fe} \mathrm{ox}=$ iron oxide, $\mathrm{py}=$ pyrite, $\mathrm{po}=$ pyrrhotite, $\mathrm{pe}=$ pentlandite $\mathrm{apy}=$ arsenopyrite, $\mathrm{gdf}=$ gersdorffite, $\mathrm{mgs}=$ magnesite, $\mathrm{cc}=$ calcite, $\mathrm{do}=$ dolomite, ank $=$ ankerite, $\mathrm{Fe}-\mathrm{karb}=\mathrm{Fe}$ carbonate, $\mathrm{Mn}-\mathrm{karb}=\mathrm{Mn}$ carbonate, $\mathrm{chl}=$ chlorite.

After splitting, the crushed subsamples were pulverised in a hardened steel bowl. The grain size of the pulp ( $>90 \%$ ) was $<100 \mu \mathrm{m}$. The total element concentrations of the pulverised rock samples were determined with an X-ray fluorescence method (performed on pressed powder pellets). The total sulphur (ISO15178) and carbon (EN13137:2001) contents were determined using a high temperature combustion method. The total inorganic carbon determination included hydrochloric acid pretreatment. The difference between the total carbon content and the carbon content from the pre-treated samples provided an estimate of the carbonate carbon content. In addition to the totals, main and trace element concentrations in the pulverised rock samples were determined with the hot aqua regia extraction method and ICP-OES (Niskavaara, 1995).

The static test for the modified NP determination followed the instructions of the preliminary standard prEN15875. Originally, it was a modification of the method by Lawrence and Wang (1997). The standard prEN15875 method does not include the Fizz test to determine the amount of acid needed, as in the modified ABA test by Lawrence \& Wang (1997). In contrast, the addition of the acid is based on the determination of total carbon content (EN13137:2001). Hydrochloric acid $(1.0 \mathrm{~mol} / \mathrm{l})$ was added to $2 \mathrm{~g}$ of pulverized subsample mixed with demineralised water until $\mathrm{pH}$ 2.0-2.5 was reached at 24 hours. After the $\mathrm{pH}$ stabilization, sodium hydroxide solution $(0.1 \mathrm{~mol} / \mathrm{l})$ was used to titrate the solution to an end-point of 8.3. The volume of $\mathrm{NaOH}$ required is a measure of how much of the input $\mathrm{HCl}$ the sample has consumed and therefore reflects the neutralization potential. The NP value from the back-titration was calculated as $\mathrm{CaCO}_{3}$ equivalents in $\mathrm{kg} / \mathrm{t}$. In comparison, carbonate NP was calculated by multiplying the carbonate carbon concentration by 83.34 to yield the NP in units of $\mathrm{kg} \mathrm{CaCO}_{3} / \mathrm{t}$. The AP was calculated from the total $S$ content of a sample, based on the assumption that each mole of sulphur present produces two moles of acid (Jambor, 2003). Because one mole of Ca carbonate (i.e. calcite $\left[\mathrm{CaCO}_{3}\right]$ ) will neutralize the two moles of acid, the sulphur content (\%) was multiplied by 31.25 to yield the AP in units of $\mathrm{kg} \mathrm{CaCO}_{3}$ equivalent per one ton of mine waste.

The procedure for the NAG test followed the instructions of the AMIRA handbook (2002). A mixture of a $250 \mathrm{ml}$ of $15 \%(\mathrm{~m} / \mathrm{V}) \mathrm{H}_{2} \mathrm{O}_{2}$ and 2.5 $\mathrm{g}$ of pulverised sample was allowed to react for about 12 hours and was then boiled until the visible reaction ceased. After cooling, $\mathrm{pH}$ and electric conductivity (EC) were measured from the NAG solution. The suspension was then titrated with $\mathrm{NaOH}(0.1 \mathrm{~mol} / \mathrm{L})$ to $\mathrm{pH} 4.5$ and 7.0 (AMIRA, 
2002). The NAG values were calculated from the consumption of $\mathrm{NaOH}$ in the titration, and expressed as $\mathrm{kg} \mathrm{H}_{2} \mathrm{SO}_{4} / \mathrm{t}$.

The AMIRA guidebook (2002) recommends using the net acid producing potential (NAPP) together with the NAG test for the classification of acid generation. The NAPP is calculated as the difference (subtraction) between the maximum potential acidity (MPA) and the acid neutralizing capacity (ANC), and it represents the balance between the capacity of a sample to generate acid (MPA) and its capacity to neutralise acid (ANC). In the present study, the ANC was converted from the NP value of the modified NP test $(\mathrm{NP} / 50 * 49)$ and the MPA from the total $\mathrm{S}$ content in units of $\mathrm{kg} \mathrm{H}_{2} \mathrm{SO}_{4} /$ t (S \% * 30.6) (AMIRA, 2002).

In addition, portions of NP and NAG extracts were separated before titrations by pipette to analyse elements solubilised during the addition of acid in the modified NP test and during the sulphide oxidation with $\mathrm{H}_{2} \mathrm{O}_{2}$ in the NAG test. Element concentrations were determined from the extracts by ICP-OES/MS.

\section{Results and discussion}

The majority of the rock samples analysed with the modified NP and NAG tests had a low total S concentration $(<0.4 \%)$, while two samples contained more than $1 \%$ S (Table 2). The soapstone (SS) and diabase (DB) samples fulfilled the inert waste criterion of $0.1 \%$ for the maximum total sulphide $S$ content set by the Finnish Mine Waste Decree 717/ 2009. The samples of mafic metavolcanic rocks (MVI and MVII), gneiss (GN) and migmatite (MG) exceeded the $S$ limit of inert waste, having a $S$ content between $0.2 \%$ and $0.4 \%$ (Table 2). Carbonate $\mathrm{C}$ concentration of these rocks was low or below the detection limit (diabase, migmatite). The intermediate metavolcanic rock (IV) and altered rock (Alt R) had high sulphide $\mathrm{S}$ and carbonate $\mathrm{C}$ concentrations (>2\%).

High total concentrations of $\mathrm{MgO}$ and $\mathrm{CaO}$ in samples of diabase, mafic (MVII) and intermediate (IV) metavolcanic rocks indicated not only the presence of carbonate minerals (see aqua regia extractable $\mathrm{Mg}$ and $\mathrm{Ca}$ in Table 4) but also the presence of $\mathrm{Mg}$ - and Ca-bearing silicates that may provide some neutralisation capacity (Table 2). These samples contained moderately reactive silicates such as hornblende, actinolite and anorthite (Ca-plagioclase) to attenuate acid production (Table 1; cf. Jambor et al., 2002). According to Jambor et al. (2002), highly calcic members of the plagioclase feldspars yield a greater neutralizing potential than the sodic members do. Gneiss and migmatite, with a lower total content of $\mathrm{Mg}$ and $\mathrm{Ca}$, mainly consist of $\mathrm{Na}$ bearing plagioclase and/or K feldspar (Table 1),

Table 2. Total S, C, non-carbonate $\mathrm{C}$ and carbonate $\mathrm{C}$ concentrations, and total main element oxide concentrations of the studied rock samples. See keys for abbreviations of the rock samples in Table 1; n.d. = no data.

\begin{tabular}{l|c|c|c|c|c|c|c|c|c}
\hline Totals & & SS & DB & MV I & MV II & GN & MG & IV & Alt R \\
\hline $\mathrm{S}$ & $\%$ & 0.07 & 0.12 & 0.19 & 0.31 & 0.33 & 0.35 & 2.50 & 8.92 \\
$\mathrm{C}$ & $\%$ & 4.48 & 0.08 & 0.91 & 0.07 & 0.22 & 0.15 & 2.54 & 7.08 \\
$\mathrm{C}$, non carbonate & $\%$ & 0.08 & 0.07 & 0.74 & $<0.05$ & 0.15 & 0.15 & 0.31 & 3.11 \\
$\mathrm{C}$, carbonate & $\%$ & 4.40 & $<0.05$ & 0.18 & 0.05 & 0.06 & $<0.05$ & 2.23 & 3.97 \\
$\mathrm{SiO}_{2}$ & $\%$ & 36.1 & 50.4 & 68.7 & 45.2 & 65.3 & 66.3 & 43.1 & 45.5 \\
$\mathrm{Fe}_{2} \mathrm{O}_{3}$ & $\%$ & 17.6 & 14.6 & 9.01 & 10.7 & 5.98 & 6.33 & 11.0 & 20.6 \\
$\mathrm{Al}_{2} \mathrm{O}_{3}$ & $\%$ & 1.98 & 13.8 & 10.7 & 9.36 & 15.9 & 17.6 & 13.2 & 6.31 \\
$\mathrm{MgO}$ & $\%$ & 34.3 & 6.69 & 4.56 & 20.0 & 2.49 & 2.02 & 5.73 & 1.69 \\
$\mathrm{CaO}$ & $\%$ & 0.75 & 10 & 0.23 & 8.00 & 1.49 & 1.26 & 10.3 & 3.82 \\
$\mathrm{Na}_{2} \mathrm{O}$ & $\%$ & $<0.07$ & 2.31 & 1.72 & 0.21 & 2.46 & 1.98 & 2.29 & 2.11 \\
$\mathrm{~K}_{2} \mathrm{O}$ & $\%$ & $n . d$. & 0.37 & 0.19 & 0.13 & 3.67 & 3.18 & 1.19 & 0.98 \\
\hline
\end{tabular}


which weather very slowly and have hardly any input into acid neutralisation (Kwong \& Ferguson, 1997; Lawrence \& Wang, 1997). In comparison, the altered rock, which consisted of reworked metasedimentary and metavolcanic materials, had a somewhat greater $\mathrm{CaO}$ content than gneiss and migmatite due to the presence of Ca-bearing carbonate minerals.

The modified NP/AP ratios (NPR) of all the other rocks, except for soapstone, varied in the range of $<1$ to 2, which classified them as 'possibly' or 'likely acid generating' materials (Table 3; ST/EIPPCP/MTWR_BREF_FINAL July 2004). Based on the Finnish Mine Waste Decree 717/2009, this type of waste is not inert. A waste with $\mathrm{S}$ content $<1 \%$ and NPR $<3$ is classified as inert. Only the soapstone sample fulfilled this criterion.

Contrary to the modified NP value, the neutralization capacity based on carbonate NP was considerably higher for the soapstone (SS), and somewhat higher for the mafic metavolcanic rock I (MVI) and altered rock (Alt R) samples, and classified them as 'non-acid generating', 'not potentially acid generating' and 'possibly acid generating' materials, respectively (Table 3). These rocks contain slowly weatherable carbonates such as magnesite and ankerite, which potentially increase the long-term neutralization capacity (Table 1 ). In contrast, the NP/AP

Table 3. Results of the modified ABA and single NAG tests and carbonate NP determinations of the studied rock samples.

\begin{tabular}{|c|c|c|c|c|c|c|c|c|c|}
\hline & & SS & DB & MV I & MV II & GN & MG & IV & Alt $\mathrm{R}$ \\
\hline $\mathrm{AP}^{1)}$ & $\mathrm{kgCaCO}_{3} / \mathrm{t}$ & 2.2 & 3.8 & 5.59 & 9.6 & 10.2 & 10.9 & 85.0 & 289 \\
\hline NP (prEN15875) & $\mathrm{kgCaCO}_{3}^{3} / \mathrm{t}$ & 53.6 & 6.65 & 9.34 & 6.07 & 6.82 & 4.38 & 182 & 89.5 \\
\hline Carbonate $\mathrm{NP}^{2}$ & $\mathrm{kgCaCO}_{3}^{3} / \mathrm{t}$ & 367 & 0.83 & 14.6 & 4.18 & 5.26 & n.d. & 186 & 331 \\
\hline \multicolumn{10}{|c|}{ Acid-base account (equivalent NPR ratios of $\mathrm{CaCO}_{3}$ ) } \\
\hline \multirow{2}{*}{\multicolumn{2}{|c|}{$\begin{array}{l}\mathrm{NP}(\operatorname{prEN} 15875) / \mathrm{AP} \\
\text { Carbonate NP/AP }\end{array}$}} & 25 & 1.8 & 1.7 & 0.6 & 0.7 & 0.4 & 2.1 & 0.3 \\
\hline & & 168 & 0.2 & 2.6 & 0.4 & 0.5 & n.d. & 2.2 & 1.1 \\
\hline \multirow{2}{*}{\multicolumn{2}{|c|}{$\begin{array}{l}\text { Classification, } \\
\mathrm{NP}(\text { prEN15875)/AP }\end{array}$}} & $>4$ & $1-2$ & $1-2$ & $<1$ & $<1$ & $<1$ & $2-4$ & $<1$ \\
\hline & & none & possibly & possibly & likely & likely & likely & low & likely \\
\hline \multicolumn{10}{|l|}{ Single NAG test } \\
\hline EC & $\mathrm{mS} / \mathrm{m} 25^{\circ} \mathrm{C}$ & 16.6 & 10.5 & 14.0 & 17.9 & 23.5 & 36.4 & 54.1 & 252 \\
\hline NAG-pH & & 9.0 & 4.1 & 7.0 & 4.9 & 3.5 & 3.2 & 8.7 & 2.8 \\
\hline NAG pH 4.5 & $\mathrm{~kg} \mathrm{H}_{2} \mathrm{SO}_{4} / \mathrm{t}$ & 0.0 & 0.2 & 0.0 & 0.0 & 1.6 & 3.8 & 0.0 & 13.5 \\
\hline NAG pH 7.0 & $\mathrm{~kg} \mathrm{H}_{2} \mathrm{SO}_{4} / \mathrm{t}$ & 0.0 & 1.0 & 0.0 & 1.3 & 3.8 & 6.6 & 0.0 & 44.1 \\
\hline \multicolumn{10}{|c|}{ Acid-base account (equivalent ratios of $\mathrm{H}_{2} \mathrm{SO}_{4}$ ) } \\
\hline $\mathrm{ANC}^{4)}$ & $\mathrm{kg} \mathrm{H}_{2} \mathrm{SO}_{4} / \mathrm{t}$ & 52.5 & 6.5 & 9.2 & 5.9 & 6.7 & 4.3 & 178 & 87.7 \\
\hline $\mathrm{MPA}^{5)}$ & $\mathrm{kg} \mathrm{H}_{2}^{2} \mathrm{SO}_{4}^{4} / \mathrm{t}$ & 2.1 & 3.7 & 5.5 & 9.4 & 10.0 & 10.7 & 83.2 & 283 \\
\hline NAPP6) & $\mathrm{kg} \mathrm{H}_{2} \mathrm{SO}_{4} / \mathrm{t}$ & -50.4 & -2.8 & -3.68 & 3.4 & 3.3 & 6.4 & -95.1 & 195 \\
\hline ANC/MPA & & 24.5 & 1.8 & 1.7 & 0.6 & 0.7 & 0.4 & 2.1 & 0.3 \\
\hline $\mathrm{NAG}_{\mathrm{pH} 4.5} / \mathrm{NAPP}$ & & 0.0 & -0.1 & 0.0 & 0.0 & 0.5 & 0.6 & 0.0 & 0.1 \\
\hline Classification $^{7)}$ & & NAF & PAF-LC & NAF & $\mathrm{UC}$ & PAF-LC & PAF & NAF & PAF \\
\hline
\end{tabular}

1) Acid potential $=31,25 * \mathrm{~S} \%$

2) Neutralization potential $=83,34^{*} \mathrm{Ckarb} \%$

3) ST/EIPPCB/MTWR_BREF_FINAL July 2004, Price et al. 1997

4) Acid neutralization capacity $=\mathrm{NP} / 50 * 49 \mathrm{~kg} \mathrm{H} 2 \mathrm{SO} 4 / \mathrm{t}$

5) Maximum potential acidify $=30,6 * \mathrm{~S} \%$

6) Net acid producing potential $=$ MPA-ANC

7) $\mathrm{NAF}=$ non acid forming (negative NAPP and NAGpH $34.5, \mathrm{NAG}=0$ ), PAF = potentially acid forming (positive NAPP, NAGpH<4.5, and NAG>5), PAF-LC = potential acid forming, low capacity (NAG $£ 5)$, UC = Uncertain, if positive NAPP and $\mathrm{NAGpH}>4.5$ 
ratio based on the carbonate NP was smaller for the rock samples with a low carbonate content or without carbonates than the modified NP/AP ratio (Table 2 and 3). This suggests that the dissolution of silicates was responsible for neutralization during the modified NP test (Kwong \& Ferguson, 1997). Therefore, the neutralization capacity of diabase, mafic metavolcanic rock II (MVII), gneiss and migmatite mainly seems to have resulted from silicate weathering and hardly at all from carbonate minerals.

Instructions for the NAG procedure determine four categories for waste classification: 'non-acid forming' (NAF), 'potentially acid forming with lower capacity' (PAF-LC), 'potentially acid forming with a high capacity' (PAF or PAF-HC) and 'uncertain' (UC; AMIRA, 2002). Based on the NAG $\mathrm{pH}$ and NAPP values, the soapstone, MVI and intermediate metavolcanic (IV) rock samples were 'non-acid forming' materials (Table 3 and Fig. 1). Diabase and gneiss had a low capacity for potential acid generation, whereas migmatite and the altered rock were unambiguously acid-forming materials. In contrast to the diabase, gneiss and migmatite, the NAG ( $\mathrm{pH} 4.5$ ) value for MVII was zero, cor- responding to the category 'non-acid generating', but the NAG ( $\mathrm{pH} 7.0$ ) value was $>0$ and classified it as 'potentially acid generating' (Table 3 ). Consequently, MVII is placed in the 'uncertain' category in Figure 1.

In the NAG test, the titration at $\mathrm{pH} 4.5$ includes acidity due to free acid (i.e. $\mathrm{H}_{2} \mathrm{SO}_{4}$ from sulphide oxidation) as well as from the hydrolysis of soluble $\mathrm{Al}$ and Fe (Miller et al., 1997; AMIRA, 2002). The NAG pH 7.0 titration value includes additional acidity due to other metals that precipitate as hydroxides between $\mathrm{pH} 4.5$ and 7.0 (AMIRA, 2002). As seen in Table 4, a considerable part of the $\mathrm{Cu}$ and $\mathrm{Ni}$ was soluble in the NAG extract of MVII. Copper and $\mathrm{Ni}$ obviously precipitate during the back-titration to $\mathrm{pH} 7$, which causes the increase in the NAG pH 7 value (Jennings et al., 2000). In contrast, both NAG pH 4.5 and 7 values indicated that the diabase, gneiss, migmatite and altered rock samples were potentially acid generating (Table 3 ).

The results of the modified NP and NAG tests and carbonate NP revealed differences in classifying the acid-generating character of the rock samples. The hydrochloric acid treatment in the modified NP test mainly solubilised reactive carbonate

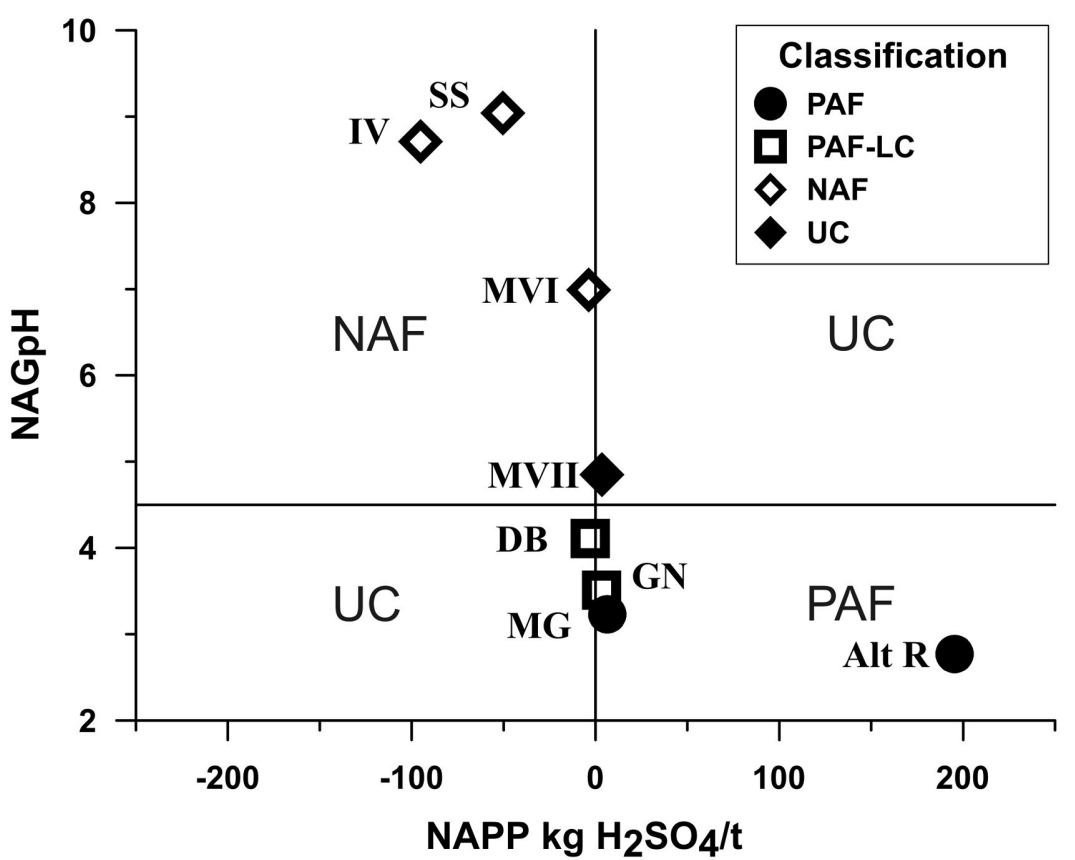

Fig. 1. Distributions of the studied rock samples in the NAG pH/NAPP diagrams. 
minerals (e.g. calcite) (see Ca extractability in Fig. 2a). However, the acid added during the test did not solubilise all the carbonates that may have neutralization potential in the long term (Table 3). Based on this, carbonate NP determination should be included in mine waste screening. The results showed that the dissolution of silicates in the samples with a low carbonate content or without carbonates yielded a minor neutralizing potential (Table 3). According to Kwong \& Ferguson (1997) and Jambor et al. (2002), silicates rarely contribute sufficient NP to surpass the threshold value (e.g. $20 \mathrm{~kg} \mathrm{CaCO} / \mathrm{t}$ ) needed to neutralize potential acidity produced by the sulphide oxidation during the test. This is despite silicate alteration (e.g. clay mineral transformation) may contribute to ARD neutralization and metal attenuation under field conditions (Alpers \& Nordstrom, 1990; Blowes et al., 1992).

Hydrogen peroxide is an aggressive reagent for oxidizing sulphides, while it less strongly attacks carbonates and silicates (AMIRA, 2002). The extractability of $S$ during the NAG test varied from $30 \%$ to $95 \%$ of the $S$ totals, while it was expectedly much lower $(<10 \%)$ during the modified NP test (Fig. 2b). According to the experiments by Jennings et al. (2000), $\mathrm{H}_{2} \mathrm{O}_{2}$ oxidation liberates acidity from Fe sulphides (pyrite, marcasite, pyrrhotite), but also from arsenopyrite, chalcopyrite and sphalerite, similarly to the sulphide oxidation caused by oxygen. However, the extractability of As was low during the NAG test, especially from the intermediate metavolcanic rock that contained abundant arsenopyrite. This indicates that a single addition of the $\mathrm{H}_{2} \mathrm{O}_{2}$ solution, as used in the present study, may not be sufficient to oxidize all the slowly reactive arsenopyrite (AMIRA, 2002). Furthermore, the coprecipitation of As with Fe during the test can also reduce the As content in the NAG extracts (Jennings et al., 2000).

Table 4 presents the concentrations of some of the main and trace elements in extracts produced by the modified NP test and NAG test in comparison to their aqua regia extractable concentrations. As can be seen, the concentrations of extractable $\mathrm{Fe}$ and $\mathrm{Al}$ were much higher in the NP than the NAG extracts. This suggests that hydrochloric acid of the NP test markedly dissolved silicates, resulting in slightly increased NP values for the low carbonate and non-carbonate rock samples. However, the increase in the neutralization capacity via silicate dissolution did not raise the NP values over the AP values in MVII, gneiss or migmatite, as was the case for diabase (Table 3). Hydrolyzation of $\mathrm{Fe}$ and $\mathrm{Al}$ generates some additional acidity in these rocks (Kwong \& Ferguson, 1997), further contributing to their classification as 'likely acid generating materials'. In contrast, the low concentrations of Fe in NAG extracts and the reddish brown colouring of the residues suggest the precipitation of Fe during the test, which obviously leads to acid release and therefore influences the NAG $\mathrm{pH}$, in addition to the release of sulphuric acid from sulphide oxidation a)

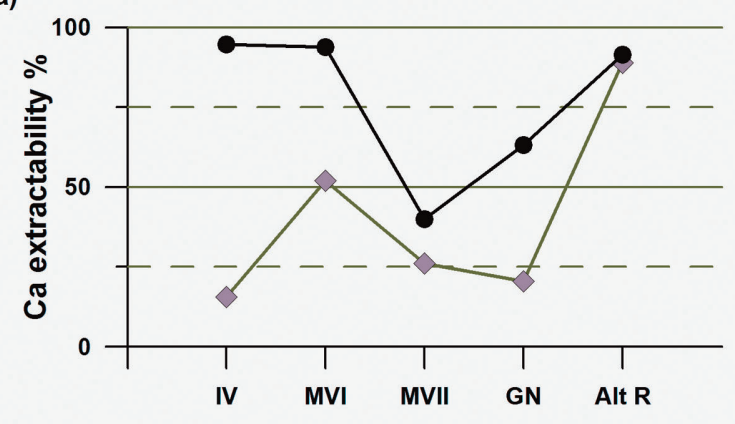

b)

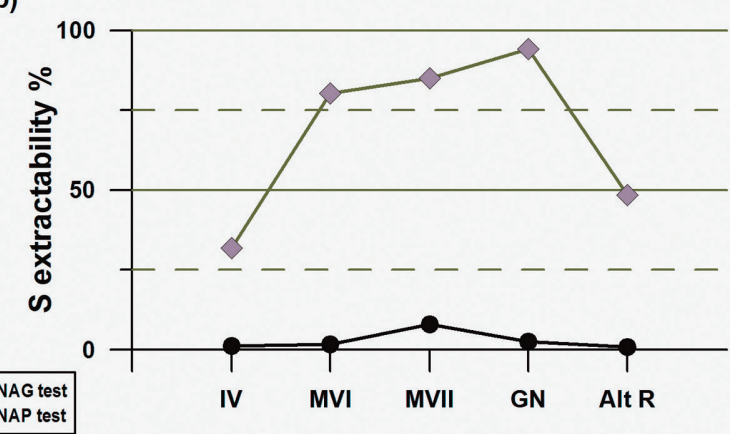

Fig. 2. (a) Ca and (b) S extractability (\%) in the NP and NAG extracts of the studied rock samples. See keys for abbreviations in Table 1. 
(Miller et al., 1997; Jennings et al., 2000). The exception to the behaviour of Fe was the sample of altered rock, which showed high extractability of $\mathrm{Fe}$ at a very low NAG $\mathrm{pH}(<\mathrm{pH} 3)$ that maintains the solubility of $\mathrm{Fe}^{3+}$ instead of re-precipitation (Table 3). Furthermore, a decrease in the NAG pH below 5 is followed by an increase in Al extractability, which upon hydrolysis generates some acid.

Furthermore, the release of trace metals unambiguously depends on the NAG pH (Table 4, Fig. 3). As seen for samples of MVII, diabase, gneiss, migmatite and altered rock in Figure 3, the relative extractability of $\mathrm{Cu}$ and $\mathrm{Ni}$ was markedly elevated when the NAG pH dropped below 5.0, regardless of their aqua regia extractable concentrations or the total sulphide $S$ content. Furthermore, the concentrations in the NAG extracts were greater than in the NP extracts (except in MVI and IV), which had a lower solubility of sulphur indicating minor decomposition of metal sulphides in the NP test. The $\mathrm{pH}$ dependence of trace solubility in the NAG extract (before the titration) is analogous to the see-

Table 4. Main and trace element concentrations in the hot aqua regia (AR), NP and NAG extracts of the studied rock samples. No NP extract data from the SS, DB and MG rock samples, keys for rock sample abbreviations in Table 1.

\begin{tabular}{|c|c|c|c|c|c|c|c|c|c|c|c|c|c|}
\hline & $\begin{array}{c}\mathrm{Ca} \\
\mathrm{mg} / \mathrm{kg}\end{array}$ & $\begin{array}{c}\mathrm{Mg} \\
\mathrm{mg} / \mathrm{kg}\end{array}$ & $\begin{array}{c}\mathbf{K} \\
\mathrm{mg} / \mathrm{kg}\end{array}$ & $\begin{array}{c}\mathrm{Al} \\
\mathrm{mg} / \mathrm{kg}\end{array}$ & $\begin{array}{c}\mathbf{F e} \\
\mathrm{mg} / \mathrm{kg}\end{array}$ & $\begin{array}{c}\mathrm{S} \\
\mathrm{mg} / \mathrm{kg}\end{array}$ & $\begin{array}{c}\text { As } \\
\mathrm{mg} / \mathrm{kg}\end{array}$ & $\begin{array}{c}\text { Co } \\
\mathrm{mg} / \mathrm{kg}\end{array}$ & $\underset{\mathrm{mg} / \mathrm{kg}}{\mathrm{Cr}}$ & $\underset{\mathrm{mg} / \mathrm{kg}}{\mathrm{Cu}}$ & $\begin{array}{c}\mathrm{Mn} \\
\mathrm{mg} / \mathrm{kg}\end{array}$ & $\begin{array}{c}\mathrm{Ni} \\
\mathrm{mg} / \mathrm{kg}\end{array}$ & $\begin{array}{c}\mathrm{Zn} \\
\mathrm{mg} / \mathrm{kg}\end{array}$ \\
\hline \multicolumn{14}{|c|}{ Soapstone (SS) } \\
\hline AR & 4890 & 89600 & $<50$ & 4100 & 93400 & 802 & 226 & 104 & 858 & 38 & 1530 & 814 & 25 \\
\hline NAG & 1330 & 1520 & $<20$ & 34 & $<20$ & 473 & 6 & 0 & 2 & 0 & $<1$ & 1 & $<1$ \\
\hline \multicolumn{14}{|c|}{ Diabase (DB) } \\
\hline $\mathrm{AR}$ & 11100 & 3140 & 1020 & 13300 & 25900 & 1200 & 1 & 16 & 35 & 138 & 190 & 31 & 37 \\
\hline NAG & 606 & 150 & 199 & 96 & $<20$ & 1070 & 0 & 7 & 0 & 89 & 15 & 17 & 16 \\
\hline \multicolumn{14}{|c|}{ Mafic metavolcanic rock I (MVI) } \\
\hline AR & 1290 & 26300 & 321 & 37900 & 61700 & 1980 & 19 & 32 & 240 & 84 & 390 & 208 & 158 \\
\hline NP & 1210 & 2390 & 98 & 4550 & 5450 & 35 & 1 & 10 & 19 & 22 & 75 & 39 & 34 \\
\hline NAG & 666 & 1080 & 21 & 55 & 61 & 1590 & $<0.07$ & 0 & 11 & 0 & 3 & 0 & 2 \\
\hline \multicolumn{14}{|c|}{ Mafic metavolcanic rock II (MVII) } \\
\hline AR & 2720 & 40000 & 374 & 28200 & 32000 & 2790 & 1 & 54 & 326 & 1650 & 409 & 778 & 99 \\
\hline NP & 1090 & 1400 & 213 & 952 & 1200 & 223 & 0 & 4 & 8 & 115 & 31 & 49 & 13 \\
\hline NAG & 710 & 883 & 313 & 41 & $<20$ & 2370 & 1 & 10 & 2 & 781 & 22 & 127 & 50 \\
\hline \multicolumn{14}{|c|}{ Gneiss (GN) } \\
\hline AR & 1510 & 13800 & 18400 & 28900 & 38100 & 2060 & 3 & 17 & 65 & 87 & 353 & 62 & 93 \\
\hline NP & 954 & 528 & 833 & 1290 & 2180 & 51 & 1 & 3 & 4 & 2 & 41 & 10 & 6 \\
\hline NAG & 309 & 316 & 875 & 254 & $<20$ & 1940 & 0 & 6 & 0 & 39 & 18 & 26 & 20 \\
\hline \multicolumn{14}{|c|}{ Migmatite (MG) } \\
\hline AR & 632 & 6280 & 4270 & 16900 & 20300 & 3140 & 1 & 14 & 92 & 113 & 53 & 66 & 41 \\
\hline NAG & 360 & 254 & 297 & 455 & 95 & 2720 & 0 & 9 & 2 & 90 & 8 & 45 & 11 \\
\hline \multicolumn{14}{|c|}{ Intermediate metavolcanic rock (IV) } \\
\hline AR & 69000 & 32700 & 2180 & 29700 & 69900 & 25200 & 15120 & 39 & 45 & 100 & 1270 & 51 & 76 \\
\hline NP & 65300 & 1820 & 675 & 1800 & 3330 & 282 & 103 & 3 & 4 & 11 & 783 & 5 & 6 \\
\hline NAG & 10800 & 14 & 591 & 74 & 10 & 8030 & 60 & 0 & 0 & 1 & 1 & $<0.1$ & 2 \\
\hline \multicolumn{14}{|c|}{ Altered rock (Alt R) } \\
\hline AR & 27000 & 9190 & 2600 & 7220 & 143000 & 88600 & 142 & 42 & 141 & 379 & 2530 & 187 & 624 \\
\hline NP & 24700 & 5560 & 566 & 1440 & 23200 & 762 & 2 & 4 & 44 & 29 & 1120 & 21 & 217 \\
\hline NAG & 24000 & 7030 & 733 & 479 & 14600 & 43000 & 2 & 20 & 5 & 189 & 2110 & 94 & 425 \\
\hline
\end{tabular}




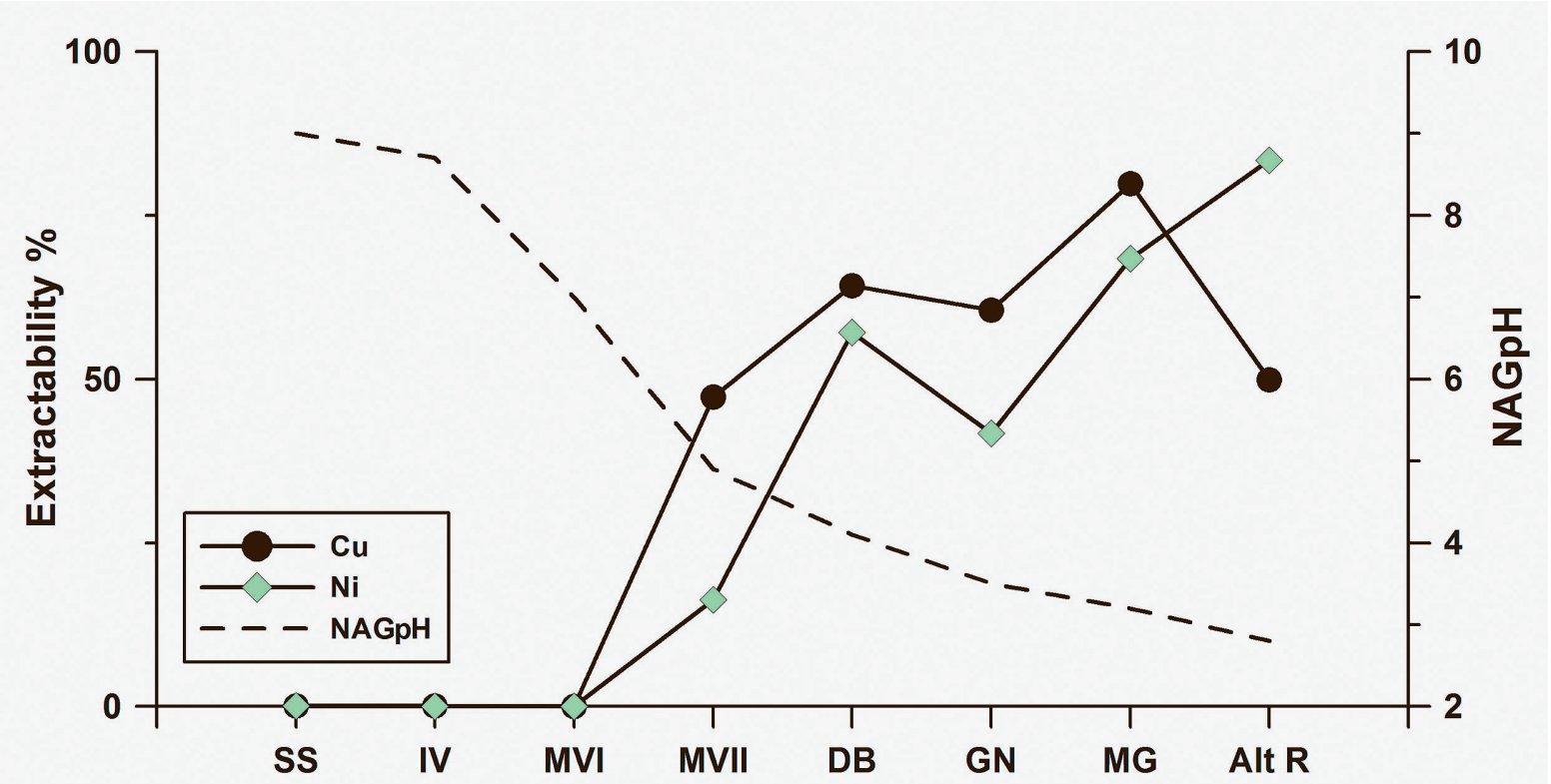

Fig. 3. NAG pH and extractability (\%) of Cu and Ni in the NAG extracts of the studied rock samples. See keys for abbreviations in Table 1.

page chemistry in the surroundings of actual waste deposits (Heikkinen et al., 2009). The solubilisation of traces during the NAG test can be interpreted to represent their maximum potential release via sulphide oxidation in the long term (Jennings et al., 2000; Weber et al., 2004; Lei \& Watkins, 2005). The acidic and Ni-rich seepage from crushed gneiss aggregates in the basal structure of a municipal waste disposal facility is also consistent with this interpretation (Table 4, Räisänen, 2005). Hydrolyzation of $\mathrm{Al}$ released in silicate weathering (obviously chlorite), following pyrrhotite oxidation, was the main source of acidity in this seepage (Räisänen, 2005; cf. Kwong \& Ferguson, 1997).

Several studies have reported the discrepancy in ARD classification between the NAG tests and the ABA tests that rely on hydrochloric or sulphuric acid treatment (O'Shay et al., 1990; Lapakko \& Lawrence, 1993; Jennings et al., 2000). This was partly also seen in this study. Both the NP and NAG tests classified diabase, gneiss, migmate and MVII into the category of 'potentially acid generating'. However, the acid production of the diabase sample, with an $S$ content below the limit $(<0.1 \%)$ for inert waste, may have been overestimated due to the additional acid released via hydrolysis of Fe and Al during the tests (Kwong \& Ferguson, 1997). Further research is needed to assess whether this reaction is valid in the actual environment, as it was in the case of gneiss aggregates. The rock sample (MVI) with slowly reactive carbonate minerals proved to be 'not potentially acid generating'/'non acid forming' according to the NAG test and the carbonate NP/AP ratio, but 'possibly acid generating' according to the $\mathrm{NP}(\mathrm{prEN} 15875) / \mathrm{AP}$ ratio (ST/ EIPPCP/MTWR_BREF_FINAL July 2004). However, the slow dissolution rate of these carbonates (i.e. ankerite) may promote ARD in the short term, and the prediction based on the NAG test or carbonate NP may therefore overestimate their actual neutralization capacity in the short term (Lei \& Watkins, 2005).

Several studies have reported the importance of mineralogical investigations together with the static test (Lawrence \& Scheske, 1997; White et al., 1999; Jambor, 2003; Weber et al., 2004; Lei \& Watkins, 2005; Heikkinen, 2009). It is also our aim in the future to examine the behaviour of different minerals during the NP and NAG tests, and to identify secondary precipitates that form. 


\section{Conclusions}

The majority of the rock samples (diabase, gneiss, migmatite, mafic metavolcanic rocks MVI and MVII) analysed with the modified NP and NAG tests had low total $\mathrm{S}$ and carbonate $\mathrm{C}$ concentrations $(<0.5 \%)$. The intermediate metavolcanic rock, altered rock and soapstone samples contained more than $2 \%$ carbonate C. The first two mentioned rocks had high $S$ contents (>2\%), whereas the soapstone had a low $S$ concentration $(<0.1 \%)$. Both the modified ABA and the NAG test classified diabase, gneiss, migmate and MVII into the category of 'potentially acid generating'. However, in case of the diabase, classified as inert waste based on the low $S$ content $(<0.1 \%)$, the tests may overestimate the acid generation potential. Nevertheless, hydrolyzation of $\mathrm{Fe}$ and $\mathrm{Al}$ released in silicate weathering, following Fe sulphide oxidation, can be one additional source of acidity attenuating the neutralization potential in low sulphide bearing wastes, as it proved to be in the case of gneiss. Furthermore, the tests unambiguously classified soapstone as 'non acid generating' and the altered rock as 'potentially acid generating'. The intermediate metavolcanic rock and MVI with slowly reactive carbonate minerals proved to be 'low and possible acid generating', respectively, according to the carbonate NP/AP ratio and the modified ABA, but 'non acid generating' (NAF) according tothe NAG test. This supports the use of the NAG test comparatively to the modified NP in mine waste screening. In the NAG test, acid generation and neutralization reactions either raising or decreasing the $\mathrm{pH}$ significantly influenced the solubility of trace metals and Al. Since $\mathrm{H}_{2} \mathrm{O}_{2}$ oxidation liberates acidity from Fe sulphides similarly to the sulphide oxidation caused by oxygen, we suggest that the NAG extract contents could be useful in assessing contaminant mobility during long-term acid generating reactions.

\section{References}

AMIRA, 2002. ARD Test Handbook. Project P387A Prediction \& Kinetic Control of Acid Mine Drainage. AMIRA international May 2002.
Alpers, C.N. \& Nordstrom, D.N., 1990. Stoichiometry of mineral reactions from mass balance computations of acid mine waters, Iron Mountain, California. In: Acid Mine Drainage - Designing for closure. Vancouver: Geological Association of Canada / Mineralogical Association of Canada Joint Meeting 1991, p. 23-33.

Blowes, D.W., Jambor, J.L., Applieyard, E.C., Reardon, E.J. \& Cherry, J.A., 1992. Temporal observations of the geochemistry and mineralogy of a sulphide-rich mine-tailings impoundment, Heath Steele Mines, New Brunswick. Exploration and Mining Geology 1 (3), 251-264.

Dagenais, A.-M. \& Grondin, L., 2006. Geochemical characterization and leaching potential evaluation of waste rock samples. Agnico-Eagle Division Régionale, Unpublished report. $35 \mathrm{p}$.

Heikkinen, P.M., 2009. Active sulphide mine tailings impoundments as sources of contaminated drainage: controlling factors, methods of characterization and geochemical constraints for mitigation. Academic Dissertation. Geological Survey of Finland, Espoo, 38 p.

Heikkinen, P.M., Aatos, S., Nikkarinen, M. \& Taipale, R., 2007. Luonnonkivituotannon sivukiviin liittyvät ympäristövaikutukset ja ympäristökelpoisuuden testaaminen. Geological Survey of Finland, Kuopio, Report S/49/0000/2007/ 53, 41 p.

Heikkinen, P.M., Räisänen, M.L. \& Johnson, R.H., 2009. Geochemical characterisation of seepage and drainage water quality from two sulphide mine tailings impoundments: acid mine drainage versus neutral mine drainage. Mine Water and the Environment 28, 30-49.

Jambor, J.L., 2003. Mine-waste mineralogy and mineralogical perspectives of acid-base accounting. In: Jambor, J.L., Blowes, D.W. \& Ritchie, A.I.M. (eds.) Environmental aspects of mine wastes. Mineralogical Association of Canada, Short Course Series 31, 117-145.

Jambor, J.L., Dutrizac, J.E., Groat, L.A. \& Raudsepp, M., 2002. Static tests of neutralization potentials of silicate and aluminosilicate minerals. Environmental Geology 43, 1-17.

Jennings, S.R., Dollhopf, D.J. \& Inskeep, W.P., 2000. Acid production from sulfide minerals using hydrogen peroxide weathering. Applied Geochemistry 15, 235-243.

Kwong, Y.T.J. \& Ferguson, K.D., 1997. Mineralogical changes during NP determinations and their implications. Proceedings Fourth International Conference on acid rock drainage, Vancouver, B. C. Canada may 31 - June 6, 1997, volume I, p. 435-447.

Lapakko. K. \& Lawrence, R.W., 1993. Modification of the net acid production (NAP) test. Proceedings of the $17^{\text {th }}$ Annual Mine Reclamation Symposium, May 4-7, Port Hardy. Vancouver: B.C. Mining Association of British Columbia, p. 145-159.

Lawrence, R.W. \& Scheske, M., 1997. A method to calculate the neutralization potential of mining wastes. Environmental Geology 32, 100-106. 
Lawrence, R.W. \& Wang, Y., 1997. Determination of neutralization potential in the prediction of acid rock drainage. Proceedings Fourth International Conference on acid rock drainage, Vancouver, B. C. Canada may 31 - June 6, 1997 , volume I, p. 451-464.

Lei, L. \& Watkins, R., 2005. Acid drainage reassessment of mining tailings, Black Swan Nickel Mine, Kalgoorlie, Western Australia. Applied Geochemistry 20, 661-667.

Miller, S., Robertson, A. \& Donahue, T., 1997. Advances in acid drainage prediction using the net acid generating (NAG) test. Proceedings Fourth International Conference on acid rock drainage, Vancouver, B. C. Canada may 31 - June 6, 1997, volume II, p. 533-547.

Niskavaara, H., 1995. A comprehensive scheme of analysis for soils, sediments, humus and plant samples using inductively coupled plasma atomic emission spectrometry (ICPAES). In: S. Autio (ed.), Geological Survey of Finland, Current Research 1993-1994, Special Paper 20, 167-175.

O’Shay, T., Hossner, L.R. \& Dixon, J.B., 1990. A modified hydrogen peroxide oxidation method for determination of potential acidity in pyritic overburden. Journal of Environmental Quality 19, 778-782.

Price, W.A., Morin, K. \& Hutt, N., 1997. Guidelines for the prediction of acid drainage and metal leaching for mines in British Columbia: II Recommended procedures for static and kinetic testing. Proceedings Fourth International Conference on acid rock drainage, Vancouver, B. C. Canada may 31 - June 6, 1997, volume I, p. 15-30.
Räisänen, M.L., 2005. Lakeuden Etappi Oy:n kaatopaikkarakennemateriaalien, savien ja murskeiden kemiallinen nykytila ja vaikutukset ympäristön vesien metalli- ja rikkisisältöön. Geological Survey of Finland. Unpublished Report, $8 \mathrm{p}$.

Sobek, A.A., Schuller, W.A., Freeman, J.R. \& Smith, R.M., 1978. Field and laboratory methods applicable to overburdens and minesoils. United States Environmental Protection Agency EPA-600/2-78-054, 47-62.

ST/EIPPCP/MTWR_BREF_FINAL July, 2004. Reference Document on Best Available Techniques for Management of Tailings and Waste-rock in Mining Activities. July 2004. European Commission, Directorate-General JRC Joint Research Centre, Institute for Prospective Technological Studies, Sustainability in Industry, Energy and Transport, European IPPC Bureau, 511 p.

Weber, P.A., Stewart. W.A., Skinner, W.M., Weisener, C.G., Thomas, J.E. \& Smart R. St. C., 2004. Geochemical effects of oxidation products and framboidal pyrite oxidation in acid mine drainage prediction techniques. Applied Geochemistry 19, 1953-1974.

White, W.W., Lapakko, K.A. \& Cox, R.L., 1999. Static-test methods most commonly used to predict acid mine drainage: practical guidelines for use and interpretation. In: Plumlee, G.S. \& Logsdon, M. (eds.) The environmental geochemistry of mineral deposits, part A: Theory and background. Reviews in Economic Geology 7A, 325-228. 